\title{
Die vermyding van etniese spanning en konflik in Suid-Afrika: Wat kan Paulus se ervaring ons leer?
}

\begin{abstract}
Author:
Markus Cromhout ${ }^{1}$

Affiliation:

${ }^{1}$ Department of New

Testament Studies,

University of Pretoria,

South Africa

Note:

Dr Markus Cromhout is a

research associate of Prof.

Dr Andries G. van Aarde at

the Faculty of Theology,

University of Pretoria,

South Africa.

Correspondence to:

Markus Cromhout

email:

markuscromhout@yahoo.

com

Postal address:

PO Box 1078, Sunninghill

2157, South Africa

Dates:

Received: 26 Jan. 2010

Accepted: 14 Apr. 2010

Published: 07 June 2011

How to cite this article: Cromhout, M., 2011, 'Die vermyding van etniese spanning en konflik in Suid-Afrika: Wat kan Paulus se ervaring ons leer?', HTS Teologiese Studies/ Theological Studies 67(1), Art. \#782, 8 pages. DOI: 10.4102/hts.v67i1.782
\end{abstract}

\section{Avoiding ethnic tension and conflict in South Africa: What can we learn from Paul's experience?}

The dream of a 'rainbow nation' in South Africa appears to be on the wane as ethnic tension and conflict seem to simmer just beneath the surface. This article investigates Paul's approach to the issue of ethnic identity with reference to ethnicity and social identity theory. Initially, Paul adopted a radical approach, which basically rendered ethnic identity irrelevant. However, he came to realise that ethnic differences need to be accommodated within the group of Jesus followers. The article applies these insights in calling for strong, moral, visionary and discerning leadership in South Africa.

\section{Inleiding}

Konflik skep konflik en om geweld met geweld te beantwoord, is klaarblyklik so deel van ons diere- en mensewêreld dat die 'spiraal van konflik' deur sommige selfs as positief gewaardeer kan word. Om konflik so as deel van menswees te sien, is egter om as slagoffer aan determinisme oorgelewer te wees.

(Van Aarde 2008a:1667-1668)

Só begin Van Aarde sy studie oor Paulus se benadering tot geweld en verdraagsaamheid, veral in soverre dit op die Suid-Afrikaanse samelewing betrekking het (vgl. Van Aarde 2008b). Hy ondersoek Paulus se mimesis-retoriek, bepaald Paulus se weergawe van Jesus se leerstelling om 'die ander wang te draai' (Matt 5:39), wat 'getuig van 'n alternatief op apokaliptiese determinisme dat mense niks aan 'n onregverdige aion kan verander nie' (Van Aarde 2008a:1671). Volgens Van Aarde is daar ' $n$ verandering te bespeur in Paulus se retoriek van vergelding. In 1 Tessalonisense praat Paulus in sterk apokaliptiese taal wanneer hy sê dat God geweld sal gebruik om geweld - veral teen die navolgelinge van Jesus - uit te wis. Stelselmatig het Paulus egter hiervan wegbeweeg, en het hy uiteindelik, soos uit die Romeinebrief blyk, Jesus se uitspraak van 'draai die ander wang' nie net verwoord nie, maar ook geïnternaliseer. Die mens sélf moet getransformeer word; met so 'n nuwe denkwyse sal jy die kwaad met die goeie kan vergeld (Rom 12:2-21). In dié trant sê Van Aarde: 'Dit lyk my dat toleransie is herdefinieer, want "hoop" is geïnternaliseer' (2008a:1686). Sodoende word die 'spiraal van konflik' (Van Aarde 2008a) hokgeslaan, en word die 'buitegroep' in die hede op dieselfde manier as die 'binnegroep' behandel - met menswaardigheid; as mense vir wie die goddelike lewegewende gawes en onderlinge liefde ook beskore is. Sedert sy uitsprake in 1 Tessalonisense, het Paulus dus 'n dramatiese ontwikkeling in denke, of psigologiese ontwikkeling, ondergaan. In plaas daarvan om dit aan God oor te laat om alles in die toekoms reg te stel; in plaas daarvan om geweld met geweld te beantwoord, moet ons - as navolgelinge van Jesus - reeds in die hede ons geloof, kragte en moeite inspan om 'n regverdige wêreld tot stand te bring.

Van Aarde (2008a:1673-1674) verwys na verskillende vorme van geweld. Vir hierdie artikel is daardie vorme van geweld met etnosentriese konnotasies veral van belang. Hierdie navorsingstuk wil op Van Aarde se insigte voortbou, en op die realiteit van 'rasse'-spanning en konflik in SuidAfrika konsentreer - veral hoe hierdie 'spiraal van konflik' (Van Aarde 2008a) aan die hand van Paulus se denkverskuiwing hanteer kan word. Een ding is seker: Die openbare diskoers in SuidAfrika word onder andere deur die konsep 'ras' oorheers. Dit is oral te bespeur. Koerante en die internet verwys telkemale daarna. Lees maar net die briewe en artikels oor rassisme. Dit beïnvloed die ekonomiese sektor in die vorm van regstellende aksie. Ook op die sportveld is dit teenwoordig in die kwotastelsel en (die gebrek aan) ontwikkeling op grondvlak. Dit steek kop uit in die huidige taaldebat met betrekking tot skole en universiteite. Straat- en dorpname word verander; grond moet herverdeel word. Dit is te bespeur in die regering se ideologie van 'transformasie', wat alle aspekte van die samelewing raak en deur wetgewing ondersteun word. Dat dít alles etniese spanning veroorsaak, blyk duidelik in die media en die algemene gevoel van frustrasie onder baie. 
Hierdie artikel het veral betrekking op verantwoordelike leierskap in Suid-Afrikaanse verband. Die aanvang van ons demokrasie in 1994 onder die versoenende leierskap van Nelson Mandela en F.W. de Klerk het die saad vir 'n 'reënboognasie' gesaai. Met verloop van tyd het die onbeholpenheid van leidende rolspelers ongelukkig duidelik geword. Tans word die kernkwessie van 'ras' nie met die nodige insig en sensitiwiteit benader nie en vir politieke voordeel misbruik, wat op sy beurt stelselmatig etniese spanning in ons samelewing aanvuur. Op enkele uitsonderings na blyk die idee van 'n 'reënboognasie' toenemend iets oppervlakkig te wees wat nie juis diep in die Suid-Afrikaanse psige wortelgeskiet het nie. Dit is polities korrek, en word in openbare optrede en spraak verwag, maar agter geslote deure en in privaat gesprekke - en kommerwekkend al hoe meer in die openbare ruimte - gaan die 'spiraal van konflik' (Van Aarde 2008a) voort. Hoe kan ons in Suid-Afrika, gedagtig aan ons kulturele diversiteit, sosiale samehang handhaaf of selfs bevorder? Dit is inderdaad ' $n$ vraagstuk van die allergrootste belang.

Hierdie artikel wil die onderwerp uit 'n sosiaalwetenskaplike hoek as 'n probleem van 'n etniese aard benader, en nie sodanig as 'n kwessie wat op 'ras' gegrond is nie. ${ }^{1}$ Etniese spanning en konflik is nie inheems in SuidAfrika nie - dit is oor sowel die millennia as wêreld heen deel van die samelewing. Dit is ook duidelik in die Nuwe Testament teenwoordig, veral waar Paulus hom beywer het om die heidene as deel van God se volk te vestig, en in sy teenstand teen etnosentriese Jesusvolgelinge. Hierdie artikel sal (1) ' $n$ bondige samevatting van die huidige besinning oor etnisiteitsteorie bied, en dit plek-plek aanvul met wat as sosiale-identiteitsteorie bekend staan, (2) die ontwikkeling in Paulus se denke oor etnisiteit aan die hand van sy briewe uitlê, en (3) 'n paar gevolgtrekkings met die oog op die SuidAfrikaanse konteks maak.

\section{Wat is etniese identiteit?}

Hierdie afdeling bied ' $n$ bondige samevatting van sommige aspekte van etniese identiteit (kyk ook Cromhout 2007, 2010; Cromhout \& Van Aarde 2006). Etniese identiteit is maar een van baie sosiale identiteite wat 'n persoon kan hê, en wissel van konteks tot konteks. In sommige kontekste is etniese identiteit belangrik; in ander weer nie. Vir sommige mense het etniese identiteit min betekenis; vir ander beteken dit alles. In sommige kontekste is etniese identiteit onaktief; in ander sosiale wisselwerkings word dit geaktiveer. Op die keper beskou, is etniese identiteit ' $n$ keuse, hoewel diegene wat aan ' $n$ bepaalde identiteit deel het dit ook as 'natuurlik' of 'Godgegewe' kan verstaan.

Etniese identiteit het eerstens betrekking op ' $n$ gevoel van groepsgebondenheid. Sosiale groepe is 'n oorsprong, of

1.Die idee van 'ras' sinspeel op ' $n$ begrip van mense wat verskille as inherent, natuurlik of geneties beskou. Ek het min simpatie met so 'n benadering, want genetiese toets het bewys dat alle na National Geographic se 'The Genographic Project' besigtg 23 November 2009 , by https://genographic.nationalgeographic.com/genographic/index.html. Uit so ' hoek beskou, is alle mense dus 'familie' van mekaar, en is verskille oppervlakkig, oftewel kulturele/mensgemaakte konstrukte. bron, van identiteit waardeur mense van 'dieselfde soort' tot mekaar aangetrokke voel. Daar bestaan 'n gevoel en opvatting van verwantskap en solidariteit; van 'ons hoort saam'; van 'n 'ons' en 'n 'hulle'. Om tot 'n uitgebreide familie te behoort wat emosionele ondersteuning, hulp en geskilbeslegting aan sy lede bied, of om deel te wees van 'n gemeenskap waar die individu met alledaagse en aanvaarde gebruike vertroud is - dit vorm deel van etniese identiteit. Dit sou ' $n$ fout wees om etniese identiteit te sien as iets wat 'objektief' of ontologies 'daar buite' bestaan. Inteendeel, etniese identiteit is in ' $n$ bepaalde beskouing van die wêreld gesetel. Etniese identiteit bestaan dus eintlik in die menslike bewussyn (kulturele konstruk), en is die gevolg van sosialisering en die alomteenwoordige kognitiewe funksie van kategorisering en stereotipering. Kategorieë skep verwagtinge, en is ' $n$ vorm van 'kennis' wat waarneming beïnloed en ingevolge waarvan nuwe ervaringe en wisselwerking met ander vertolk en uitgeleef word. Sosiale kategorieë reduseer die samelewing tot 'ons' en 'hulle', en is die brein se manier om hom teen oorstimulasie te beskerm. Sulke kognitiewe raamwerke is oor die algemeen moeilik om te ontgroei, maar kan nie as 'n verskoning gebruik word om nuwe denkwyses te vermy nie. Indien 'n mens van hierdie primitiewe breinfunksie bewus is, kan jy dit ook doelbewus teenstaan om ander denkwyses te aanvaar.

Die kategorieë en opvatting van 'ons' en 'hulle' kan groepsverhoudinge negatief beïnvloed, veral waar mededinging en die persepsie van sosiale ongelykheid ter sprake is (vgl. Brown 1995, 2001; Dovidio, Gaertner \& Validzic 1998; Tajfel 1978, 1981; Tajfel \& Turner 1979). Een aspek wat te algemeen in hierdie verband voorkom, is die totstandkoming van stereotipes, wat normaalweg op die positiewe tipering van die 'binnegroep' teenoor die negatiewe tipering van die 'buitegroep' neerkom. Stereotipering behels ook evalueringsen emosionele aspekte waardeur lede van ' $n$ bepaalde etniese groep 'n positiewe selfbeeld probeer bevorder. So ' $\mathrm{n}$ positiewe selfbeeld is moontlik indien jou eie groep gunstig met ander etniese groeperinge vergelyk. In hierdie proses word verskille (tussen groepe) en gelyksoortigheid (van deelnemers aan sowel die 'binne-' as die 'buitegroep') oordryf, soos in Titus 1:12, wat lui: 'Die Kretensers is altyd leuenaars, ongediertes, lui vrate'. Hierdie soort sosiale spel is maar net te bekend in Suid-Afrikaanse verband: 'Ons is sus'; 'hulle is almal so'; 'ons is beter/die beste'. Mense word tot blote verteenwoordigers van ' $n$ bepaalde groep se sogenaamde stereotipiese gedrag en sienswyses gereduseer, terwyl die groep op sy beurt in 'n sosiale hiërargie van goed na swak ingedeel word. In die proses gaan menswaardigheid, objektiwiteit en toereikendheid verlore.

Buiten groepsgebondenheid, het etnisiteit tweedens met sosialisering te doen. Etnisiteit kan regstreeks verbind word aan hoe iemand grootgeword het sowel as die totstandkoming van habitus, oftewel 'n persoon se groeivorm of gewoonteneigings ('habitual dispositions'; vgl. Bentley 1987; Bourdieu 1977). Terselfdertyd behels etnisiteit sosiale wisselwerking met buitegroepe anderkant die etniese grenslyn. In hierdie verband geld twee teorieë, naamlik 
konstruksionisme en primordialisme (vgl. Duling 2005, 2008a, 2008b; Esler 2003a). Konstruksionisme is die mees algemeen aanvaarde teorie wat verduidelik dat etniese identiteit nie inherent of natuurlik is nie, maar sosiaal gekonstrueer word. Etnisiteit word gekies, en verander mettertyd. Al verander die kulturele inhoud van die groep, bly die groep egter bewus van hul eiesoortigheid. Wat belangrik is, is hóé en wáárom groepe etniese grenslyne konstrueer wat 'ons' van 'hulle' onderskei, met ander woorde, hoe of waarom mense hulsélf, en nie bepaalde kulturele aspekte of inhoud van die groep nie, sosiaal organiseer.

Konstruksionisme kan as 'n reaksie op primordialisme, oftewel die wanvoorstelling van primordialisme, beskou word. Primordialisme was bevraagteken omdat dit etniese identiteit beskou as 'natuurlik', 'inherent' en 'onveranderlik', maar waarop dit konsentreer is hoe mense hul eie identiteit ervaar, met sterk klem op die psigologiese en emosionele bande wat mense byvoorbeeld op grond van kultuur (soos godsdiens, taal, familie, grondgebied en gebruike) aanknoop. Primordialisme moet in sekere kontekste in aanmerking geneem word omdat etniese identiteit onverklaarbaar sal wees indien daar van die oortuiging uitgegaan word dat etniese groepering net oor (dis)assosiasie gaan. Hoekom sal mense hulle in die eerste plek só organiseer? Etniese identiteit en gebruike is vir baie mense van groot waarde. Dit gee sin; gaan oor die behoud van tradisies en gebruike; vorm ' $n$ brug met die verlede, en lê die grondslag vir die groep se voortbestaan.

Etniese identiteit word dus sosiaal gekonstrueer. Hóé dit gekonstrueer word, hang af van die sosiale konteks en mense wat daarby betrokke is. Soms word etniese identiteit deur die beklemtoning van tradisionele gebruike oorgedra; ander kere is daar meer verandering ter sprake. Meestal is etniese identiteit egter ' $n$ kombinasie van die oue en die nuwe. In sekere kontekste word dit selfs gemanipuleer om ekonomiese of politieke voordeel daaruit te trek (die Engelse 'instrumentalism'). Wanneer 'n etniese groep byvoorbeeld sterk teenkanting ervaar, hou sodanige groep gewoonlik eng vas aan die etnisiteitsmerkers wat teengestaan of bevraagteken word, en sal daardie merkers juis in die groep beklemtoon word. In hierdie verband dien die Makkabeërtydperk as voorbeeld: In reaksie op onderdrukking het kulturele gebruike soos die besnydenis, die Sabbatsgebod, en voedsel- en reinheidswette sterk in die Israelitiese bewussyn na vore getree. In die hedendaagse Suid-Afrikaanse konteks is dit opvallend hoe sterk mense op dorp- en straatnaamveranderinge en die taalkwessie in skole en universiteite reageer. Ook in die swart gemeenskap is daar groepe wat hulself vir die behoud van hul tradisionele kultuur beywer.

Derdens behels etniese identiteit ' $n$ gemeenskaplike kultuur, oftewel die behoefte om ' $n$ betekenisvolle lewensruimte te deel. Om aan ' $n$ etniese identiteit deel te hê beteken om tot ' $\mathrm{n}$ gedeelde 'kennis' of verwysingsraamwerk toegang te hê. Hiervan is die Israeliete weer 'n voorbeeld: Die Israelietiese volk het sekere kernwaardes gehad wat alle sosiale wisselwerking, groepsverhoudinge en persoonlike gedrag gerig het. Hierdie kernwaardes was onder meer hul
Godsbegrip (Jahweh is as die enigste God beskou, met ander woorde monoteïsme); hul selfbeskouing as ' $n$ heilige en uitverkore volk, met die verbond en verkryging van die wet tot hul voordeel; die mite van 'n gemeenskaplike voorgeslag, waar jy van eerbare herkoms was indien jy tot die nageslag van die voorvaders behoort het, en 'n gemeenskaplike geskiedenis. Wat laasgenoemde betref, was dit belangrik om te onthou hoe God met die voorvaders 'n verbond gesluit het; die volk uit slawerny gelei het; die koninkryk van Israel opgerig het, sowel as ander geskiedkundige gebeure. Neerlegging by hierdie kernwaardes was belangrik as jy jouself as ' $n$ Israeliet beskou het - dit was die norme en standaarde aan die hand waarvan mede-Israeliete jou gedrag kon beoordeel.

Bogenoemde kernwaardes is gerealiseer deur wat breedweg 'sosiale instellings' genoem kan word - deur binne die raamwerk van bepaalde sosiale ruimtes te leef wat aanvaarbare gedrag voorgeskryf het. Hierdie sosiale instellings sluit in die familie ('kinship'), kulturele gebruike of tradisies, 'n grondgebied, godsdiens, taalgebruik, en die naam van 'n etniese groep (vgl. beskrywings in Van Eck 2009:3-4). Voorbeelde hiervan sluit in die onderhouding van die kashrut en reinheidswette, pelgrimstogte na Jerusalem, die behoud en voortbestaan van ' $n$ rein bloedlyn deur familieen endogamiese huwelikspraktyke, om die land as familieerfenis te bewerk en te behou, sowel as die onderhouding van die Sabbat.

Die belang van bogenoemde etnisiteitsmerkers vir Israel blyk gedeeltelik uit wat Paulus aan die Romeine skryf. Paulus skryf soos volg oor sy groot droefheid en voortdurende hartseer:

...oor my broers, my eie volksgenote...Hulle is tog Israeliete; vir hulle het God as sy kinders aangeneem en in sy heerlikheid was Hy by hulle; met hulle het Hy die verbonde gesluit en aan hulle die wet van Moses gegee, asook die tempeldiens en die beloftes; hulle stam van die aartsvaders af [vgl. nakomelinge van Abraham (vers 7)], en uit hulle is die Christus as mens gebore.

(Rom 9:3-5, NAV [Outeur se beklemtoning])

Hiermee bied Paulus ons ' $n$ blik op die Israelitiese simboliese universum, of selfbegrip. Hier moet beklemtoon word dat dit verkeerd sou wees om te dink dat die Israeliete 'n vorm van 'godsdiens' beoefen het. Uit 'n sosiaal-wetenskaplike hoek is dit duidelik dat 'godsdiens' maar een deel van hul etniese identiteit uitgemaak het. In die antieke wêreld was daar nie sprake van 'godsdiens' as aparte lewensruimte, soos dit vandag funksioneer, nie.

Vir die beperkte doeleindes van hierdie navorsing is bogenoemde beskrywing van etniese identiteit, synde 'n produk van groepsgebondenheid, sosialisering en gemeenskaplike kultuur, voldoende. Vervolgens kom Paulus se aanvanklike begrip van etnisiteit, en sy ervaring en ontwikkeling wat betref etnisiteit, nou aan die orde.

\section{Paulus en etniese identiteit}

Teorieë oor etniese identiteit kan, met die nodige omsigtigheid, op die Nuwe Testament toegepas word. In 
die antieke Mediterreense wêreld is die Israeliete sonder veel inspanning as 'n eiesoortige ethnos erken; 'n groep met vreemde kultuurgebruike, en met Judea - met die klem op die tempel in Jerusalem - as hul land van herkoms. As ' $n$ volk in Palestina, of as ' $n$ minderheidsgroep in die diaspora, was hulle meestal onder politieke, sosiale, ekonomiese en kulturele druk, en uitgelewer aan die goedhartigheid of onderdrukking van verskeie ryke en owerhede. Ten spyte hiervan, het hulle sosiale en veral kulturele integrasie suksesvol teengestaan. Dít beteken nie dat hulle hulself heeltemal van die samelewing geïsoleer het nie (vgl. Harland 2003), maar om in so ' $n$ mededingende (agonistiese) konteks te kon voortbestaan moes die Israeliete deurlopend ' $n$ positiewe selfbeeld bevorder (vgl. Gruen 2002). Hoekom sou 'n mens immers tot die Israelitiese ethnos behoort as daar soveel ander identiteite was wat veel meer voordele ingehou het?

In so 'n sosiale konteks is dit tipies om sodanige 'nadelige' groepverwantskappe te behou as dit aan positiewe waardes verbind word, en só 'n positiewe selfbeeld te vestig. Vir die Israeliete het hul identiteit baie 'voordele' ingehou wat op die onderhouding van die wet gegrond was (soos eer as God se uitverkore en bevoordeelde volk, geregtigheid, 'ware kennis' en reinheid). Hul gekonstrueerde simboliese universum was dus tot oorlopens toe vol van diepe betekenis waarvolgens hulle hulself as 'beter' en meer eerbaar as ander ethne beskou het. Vir die Israeliete was hul kultuur, 'kennis', Godsbegrip en moraliteit ongeëwenaar. Dit is in dié verband dat ons Paulus se eie ervaring moet waardeer.

Wat Paulus, as apostel onder die heidene, se denkverskuiwing oor etnisiteit betref, kan die volgende twee punte uitgewys word: Aanvanklik het Paulus, as navolger van Christus, 'n radikale standpunt teenoor tradisionele etniese identiteit ingeneem - dermate dat etniese identiteit as betreklik onbelangrik of waardeloos geag is. Mettertyd swaai die pendulum egter halfpad terug. Hoewel Paulus se eie Israelitiese etniese identiteit betreklik onbelangrik gebly het, het hy besef dat hy die Israeliete, vir wie etniese identiteit steeds belangrik was, in die geloofsgemeenskap in ag moes neem.

\section{Die pendulum swaai erg}

Paulus was 'n Israeliet, maar sy ontmoeting met, en daaropvolgende navolging van, Christus het 'n onstuitbare impak op sy selfbegrip sowel as sy siening van ander gehad. Sy rotsvaste etniese identiteit het verbrokkel, en is heromskryf. Dít blyk duidelik uit die volgende voorbeelde uit Paulus se briewe. In die Filippensebrief voer Paulus 'n stryd met die Israeliete wat op die besnydenis en gehoorsaamheid aan die wet aandring, en gee hy die volgende beskrywing van sy vorige lewe (vgl. Duling 2008a):

ek is op die agste dag besny, van geboorte 'n Israeliet, uit die stam Benjamin, 'n egte Hebreër, in wetsopvatting was ek 'n Fariseër, in my ywer 'n vervolger van die kerk, in onderhouding van die wet van Moses om vryspraak te kry, onberispelik. Maar wat eers vir my ' $n$ bate was, beskou ek nou as waardeloos ter wille van Christus.
Paulus verwys na die Israeliete wat vir sosiale status in die kring van die Jesusnavolgers op hul identiteit staatmaak. By implikasie moes die heidene (byvoorbeeld deur die besnydenis) Israeliete word om soortgelyke status te bekom. Die apostel Paulus waarsku die heidene deur na homself as voorbeeld te verwys. Volgens die apostel kan hy ook groot aansien as Israeliet geniet. Tog beskryf hy hierdie beheptheid met Israelitiese identiteit, wat tradisioneel aan die Israeliet 'n eervolle posisie en voordeel bo die heidene gegee het, as 'waardeloos' en selfs 'verwerplik' (Fil 3:8). Kennis van Christus beteken nou vir hom alles. Die apostel toon hier maar min simpatie met sy volksgenote se tradisionele selfbegrip en eer. Op 'n soortgelyke manier verwys Paulus in 2 Korintiërs na die 'superapostels' wat hulle op hul etniese identiteit beroem. Hy verdedig homself soos volg: 'Is hulle Hebreërs? Ek ook. Is hulle Israeliete? Ek ook. Stam hulle van Abraham af? Ek ook' (2 Kor 11:22 [Outeur se beklemtoning]). Hoewel Paulus dus in alle opsigte dié 'superapostels' se gelyke is, beweer hy dat al hierdie statuskenmerke uiteindelik nie veel beteken nie (vgl. Duling 2008b).

In albei bogenoemde voorbeelde verwys Paulus direk of indirek na die 'voordele' wat Israelitiese etniese status inhou, en na dit wat as vanselfsprekend aanvaar is. Soos dié artikel vroeër reeds noem, is sulke sosiale speletjies tipies in kontekste van groepsmededinging. Net soos die Grieke en die Romeine, het die Israeliete hul eie groepsidentiteit etnosentries as 'beter' of 'die beste' beskou. In Romeine 3:1 vra Paulus dan ook: 'Het dit dan enige voordeel om 'n Jood te wees...?' Dit is belangrik dat Paulus dié vraag vra terwyl hy die Israeliete en heidene as sondaars, maar ook as aanspraakmakers op God se genade deur die opofferende dood van Jesus, op gelyke voet plaas.

Vir Paulus was die sosiale speletjie van 'voordeel' bo die heidene iets van die verlede. Hy openbaar duidelik 'n ander denkwyse. Paulus het dus tot ' $n$ nuwe begrip van 'ons' en 'hulle' en nuwe stereotipes gekom. 'Ons' (Israeliete en heidene) is nou die navolgers van Jesus; 'hulle' is die Israeliete en heidene wat nie in Jesus glo nie (vgl. 1 Kor 1:22-24, 10:32; Gal 3:28, 6:15-16; kyk Esler 1998:89; Taylor 2002:752). Paulus stereotipeer Jesus se volgelinge as diegene wat in die lewensruimte van die Gees bestaan, en die nievolgelinge as diegene wat in die lewensruimte van die vlees leef (Esler 1996:231). Paulus het 'n nuwe en inklusiewe ethnos, of (fiktiewe) familie, betree - 'n nuwe ethnos met sy eie grenslyne, waardes en kennisvorme; 'n ethnos wat ' $n$ nuwe afstammeling (genos) van Abraham vergestalt (Duling 2008a:814).

Paulus se eerste verwysing na die samestelling van God se volk, en etniese spanning, is in die Galasiërsbrief. Hier praat Paulus ook oor sy vorige lewe as Israeliet:

Julle het immers gehoor van my optrede toe ek destyds nog 'n aanhanger van die Joodse leer was...En in die Joodse leer het ek onder my volksgenote bo baie van my leeftyd uitgestyg, want ek was ' $\mathrm{n}$ fanatieke yweraar vir die oorgelewerde leer van my voorvaders.

(Gal 1:13-14) 
As Fariseër het Paulus hom met mening vir'n eng, tradisionele kulturele lewe en die handhawing van die grenslyn tussen Israeliet en heiden beywer. Ná sy ontmoeting met Christus het sy denkwyse oor hierdie sake egter radikaal verander. In teenstelling met sy vorige oortuigings, het hy nou die evangelie van God se Seun aan die heidennasies verkondig (Gal 1:16). Wat Petrus en ander gedoen het deur nie saam met die heidene te wil eet nie, was om weer die grenslyn tussen Israeliet en heiden op te rig, en van die pad van die evangeliese waarheid af te wyk (Gal 2:11-14). In dié verband beskryf Paulus aan die Galasiërs wat hy 'kamtig' aan Petrus gesê het:

Ons is Jode van geboorte en nie sondaars uit die heidene nie. En tog weet ons dat ' $n$ mens nie van sonde vrygespreek word deur die wet van Moses te onderhou nie, maar alleen deur in Jesus Christus te glo. Ook ons het tot die geloof in Christus Jesus gekom, en dit is hoe ons vrygespreek is: deur in Christus te glo en nie deur die wet te onderhou nie, want geen mens word vrygespreek op grond daarvan dat hy die wet onderhou nie.

(Gal 2:15-16 [Outeur se beklemtoning])

Om die 'wet te onderhou' dui nie op die Israeliete se sodanige 'godsdienstigheid' nie, maar op hul gemeenskaplike deel in hul etniese identiteit. Uit 'n sosiaal-wetenskaplike hoek beskou, sinspeel dit op die Israeliete se primordialisme, en die wyse waarop hulle hulself sosiaal organiseer. Lojaliteit teenoor God, jou kultuur en mede-Israeliete gaan hier hand aan hand met die bevordering van groepsidentiteit. Die verhouding wat Israeliete met God en mekaar gekoester het, was dus nie in wese op 'n 'teologie' gegrond nie, maar hoofsaaklik op sosiale bande wat deur 'n gemeenskaplike onderhouding van kultuurtradisies gehandhaaf is. Dit was 'n lewenswyse, nie 'n belydenis nie - dit was etnisiteit as 'sosiale aktiwiteit' (Hall 1997:25). As 'n agonistiese kultuurgroep van 'diadiese', oftewel groepsgerigte, persone (Malina 1993), het die klem op 'ortopraksie' (byvoorbeeld die onderhouding van die wet), en nie op ortodoksie nie, geval (vgl. Cohen 1987:61,103; Schmidt 2001:25). Ortopraksie is dus om tot die groep te behoort, en om aan die sosiale verwagtinge van jou mede-Israeliete te voldoen, aangesien húlle, en nie jyself nie, oor jou menswaardigheid en bevoegdheid as Israeliet besluit. Eng vorme van ortopraksie versterk en handhaaf dus interne groepsidentiteit (Bell 1997:193). Etniese identiteit as 'n groepsgerigte verskynsel berus sterk, hoewel nie alleenlik nie, op die verlede as verwysingsraamwerk. Israeliete as groepsgerigte mense was sosiaal geprogrammeer om aan die tradisies van hul voorvaders getrou te bly en dit in die hede uit te leef (vgl. De Vos 1975:17-19; Malina \& Neyrey 1996:166).

Dít impliseer dat mense hul eiesoortigheid en verwantskap met hul ethnos oorgedra het deur aan die kulturele praktyke (rituele en sosiale omgang) van die groep deel te neem. Josefus verwys na afvallige Israeliete as diegene 'wat die tradisies van die Judeërs haat' of 'wat nie die tradisies van die voorgeslagte navolg nie' (B.J. 7.50; Ant 20.100). Die heidene wat hul tot die Judaïsme bekeer het, beskryf hy as diegene wat deur besnydenis 'die tradisies van die voorgeslagte aangeneem het' (Ant 20.17,41). Om dus die 'wet te onderhou'
(Gal 2:15-16) verwys na die Israelitiese mentaliteit van 'n eksklusiewe en etnosentriese lewens- en sosiale praktyk, wat in daardie stadium as lojaliteit teenoor God en sy volk beskou is. Vir die Israeliete was hul etniese identiteit en sosiale praktyke 'Godgegewe'. Israeliet-wees was om as 'n goeie en eerbare mens en as deel van die 'regverdiges' bekend te wees.

Paulus verskil egter skerp met hierdie siening. Hy soek nie meer die guns of goedkeuring van mense nie (Gal 1:10), en stel nie daarin belang om ' $n$ uiterlike indruk in die vlees te maak (Gal 6:12-13), met ander woorde om aan die tradisionele verwagtinge van die Israelitiese ethnos gehoor te gee nie. Nou hang hy alternatiewe waardes en sosiale praktyke aan - 'n nuwe verbond en 'n nuwe ethnos wat van God kom en deur Jesus Christus bekragtig is.

In hierdie verband is Dunn $(1990,2008)$ se 'nuwe beskouing van Paulus' van belang. Dunn betoog oortuigend dat dit hier nie vir Paulus om 'n nougesette begrip van 'instellings' ('works') gaan nie, maar dat hy hom teen bepaalde instellings uitspreek (die besnydenis, Sabbat, voedselwette), synde sosiale versperrings waarmee Israeliete hulself omhein. Dit verwys ook indirek na die dieper inhoud of waardes van die Israelitiese ethnos. Ons kan Paulus se argument dus soos volg konstrueer: Hy bied sterk teenkanting teen die Israeliete se selfbeheptheid met tradisionele etniese kenmerke (God, eer, geregtigheid en verlossing) as iets wat 'net aan ons mense, die Israeliete, behoort'. Vir Paulus was die reg op volle verlossing, 'n volle verhouding met God, of status as God se volk nie meer tot Israelitiese identiteit beperk nie, want dit maak nie saak of iemand Jood of Griek is, besny of nie besny is nie (Gal 3:28). Wat wél belangrik is, is geloof in Christus, ${ }^{2}$ die uitwerking van geloof deur liefde, en die nuwe mens (Gal $5: 11,6: 15)$.

Paulus beeld die onbelangrikheid van tradisionele etniese identiteit ook elders uit (kyk 1 Kor 7:19; 2 Kor 5:16-17). Dít is veral duidelik uit Paulus se benadering tot evangelisasie:

Vir die Jode het ek soos 'n Jood geword om Jode te wen...ek [het] vir dié wat sonder die wet is, geword soos een sonder die wet om hulle te wen...Vir almal het ek alles geword om in elk geval sommige te red.

(1 Kor 9:20-22)

Vir Paulus was Israelitiese etniese identiteit dus 'n keuse; iets om na gelang van omstandighede te gebruik of neer te lê. Wat vir Paulus belangrik was, was die eenheid in die geloofsgemeenskap, waar hulle om dieselfde tafel sit, en gemeenskap met die liggaam en bloed van Christus deel (vgl. 1 Kor 8:7-13, 10:14-32, 11:17-34). Om in die eerste-eeuse Mediterreense wêreld ' $n$ tafel te deel het baie gesê oor wie jy as deel van jou 'binnegroep' beskou; waar jy jou sosiale grenslyne trek, en waar jy jou in die sosiale hiërargie plaas.

Vir Paulus was tradisionele etnosentriese gebruike nie op die navolgers van Jesus van toepassing nie, en dus het hy

2.Tensy Paulus hiermee 'lojaliteit van Christus' (Gal 2:16,20; 3:22; Rom 3:22,26; Fil 3:9) bedoel, wat na Jesus se eie gehoorsaamheid aan God tot die dood toe verwys (vgl. Hays 2002; Hooker 1990:165-186; Johnson 1982). 
in sy sosiale praktyk inklusiwiteit gepredik (vgl. Cromhout 2009; Van Eck 2009). In 1 Korintiërs 9:20-22 bespeur ons egter ook ' $n$ denkverskuiwing by Paulus, naamlik om wél verskeidenheid in die geloofsgemeenskap in ag te neem. Hierdie nuwe denkwyse ontwikkel Paulus verder in sy Romeinebrief.

\section{Die pendulum swaai so effe terug}

Paulus se houding moes vir die meeste Israelitiese navolgers van Jesus verbysterend gewees het. Stelselmatig het hy die voordele van Israelitiese identiteit bevraagteken, identiteitsmerkers ondermyn, en die grensmure met heidene oorgesteek. Altesaam moes dit seer seker die verspreiding van die evangelie onder mede-Israeliete bemoeilik het.

In die Romeinebrief kom ons egter ' $n$ 'ander soort' Paulus met 'n ander denkwyse teë. Heel waarskynlik het Paulus besef dat die 'identiteitsdood' wat hy self gesterf het, nie vir almal, veral die Israeliete, beskore was nie. Die brief aan die Romeine is aan ' $n$ gemeente onder etniese spanning gerig. Paulus wou dus gebroke verhoudings herstel, en 'n verenigde gemeente tussen Israeliet en heiden help vestig (Beker 1986; Miller 2001). In die Romeinebrief is Paulus se benadering tot etniese identiteit opvallend anders as in Filippense, Galasiërs en 2 Korintiërs. Volgens Esler (2003a, kyk ook 2003b, 2003c) het Paulus sy hardhandige benadering ten opsigte van etnisiteit as sogenaamde 'verdeler' verander, weens die negatiewe reaksie op sy werk in Galasië. Waar hy vroeër redelik onsensitief daarvoor was, wil hy nou etniese diversiteit in ag neem (Rom 14:1-15:11). In 'n poging om etniese spanning en konflik tussen Jesusvolgelinge in Rome te verminder betoog Paulus dat die gelowiges in Rome dit moet internaliseer dat hulle as 'n nuwe groep aan Christus behoort. Hulle het ' $n$ nuwe kategorie betree waardeur hulle 'n gemeenskaplike 'binnegroepsidentiteit' ('n 'hoër' identiteit) verkry het. Hierdie gemeenskaplike identiteit maak volgens Paulus ook voorsiening vir die voortbestaan van subidentiteite. Paulus pas sy boodskap aan om in die verskillende behoeftes van die verskillende groepe in Rome te voorsien. In Romeine 1-11 sit Paulus daarom die grondslag, eienskappe en doelwitte van die nuwe groep, synde Joodse én nie-Joodse Jesusnavolgers, uiteen, waarna hy in Romeine 12:1-15:13 die vereiste norme beskryf wat nodig is om die identiteit van die nuwe groep te behou en uit te bou.

Wat Paulus se konstruksie van 'n gemeenskaplike identiteit betref, sê hy:

Christus is tog die einde van die wet, sodat elkeen wat glo, vrygespreek kan word...Dit maak dus geen verskil of ' $n$ mens ' $n$ Jood of ' $n$ Griek is nie, want dieselfde Here is Here van almal, en Hy seën almal wat Hom aanroep.

(Rom 10:4,12)

Terselfdertyd neem Paulus ook die behoeftes van subidentiteite, veral dié van Israeliete, in ag:

Een glo 'n mens mag alles eet; 'n ander is swak in die geloof, en hy eet net groente...Vir die een is een dag belangriker as ander dae; vir ' $n$ ander is alle dae ewe belangrik. Elkeen moet net in sy eie gemoed oortuig wees van sy opvatting.

(Rom 14:2-5)
Wat Paulus in wese hier sê, is dat Israeliete volgens hul kultuur kán leef. Wat egter belangrik is, is dat navolgers van Jesus ook na mekaar se behoeftes moet omsien, en nie net op hul eie oortuigings moet aandring nie. Die eiebelang van subidentiteite moet deur die omvattender groepsbelange van die liggaam van Christus getemper word, want 'niemand van ons leef tog vir homself nie, en niemand sterf vir homself nie' (Rom 14:7). Paulus laat dus die voortbestaan van subidentiteite toe. Dít mag egter nie as 'n verskoning gebruik word om absolute sosiale grenslyne te skep nie. Enige vorm van selfbeheptheid moet vir gemeenskaplike sosiale praktyke en doelwitte plek maak, want 'as ons lewe, leef ons tot eer van die Here' (Rom 14:8). Aan die einde van die brief doen Paulus dan ook die volgende beroep op die kultuurdiverse gemeente: 'Aanvaar mekaar dan, soos Christus julle ook aanvaar het' (Rom 15:7). Hierop volg die insluiting van OuTestamentiese tekste waar Israeliete en heidene die Here gesamentlik prys (Rom 15:9-12).

In Romeine 12:1-13:10 gebruik Paulus ook uitsprake wat op die familie, bepaald op broers (en susters), betrekking het. In die antieke wêreld was hierdie verhoudinge van die sterkste emosionele bande wat daar was. Broers mag byvoorbeeld nie om eer meegeding het nie, maar moes eerder mededeelsaam wees. Paulus verwag dieselfde denkwyse van die gemeente (Taylor 2005). As lede van die liggaam van Christus roep hy hulle daarom soos volg op: 'Betoon hartlike broederliefde teenoor mekaar; bewys eerbied teenoor mekaar...Wees eensgesind onder mekaar. Moenie hooghartig wees nie' (Rom 12:10,16). Wat Paulus hier wil bevorder, is die oortuiging dat mense mekaar as deel van die 'binnegroep' moet beskou; mekaar moet aanvul, en nie om sosiale status, eer, identiteit en regte moet wedywer nie. Die gemeenskaplike doelwit en identiteit as ' $n$ familie in Christus wat Paulus hier skep, het dan juis ook ten doel om die 'spiraal van konflik' (Van Aarde 2008a) hok te slaan. So 'n lewe sal die apostel se wens vervul dat God hulle sal verander deur 'hulle denke te vernuwe' (Rom 12:2). Die apostel Paulus bied dus visionêre en insigryke leierskap.

\section{Sosiale samehang in Suid-Afrika Wat kan ons van Paulus leer?}

Etniese konflik in Suid-Afrika kan nie van die geskiedkundige sosiale, politieke en ekonomiese realiteite van ons land geskei word nie. Studies oor etniese verhoudinge wys daarop dat interetniese samewerking meer dikwels voorkom waar die verhoudinge tussen etniese groepe sterk gestruktureer is; verskillende en/of aanvullende sosio-ekonomiese of gebiedsnisse in ag geneem word; politieke mag op 'n wedersyds aanvaarbare, hoewel nie noodwendig gelyke nie, grondslag versprei is; verskillende ethne gelyktydig in dieselfde gebied woon, of verskillende ethne oor 'n gemeenskaplike taal, wêreldbeskouing en waardestelsel beskik. Hierteenoor kom etniese konflik meer gereeld voor waar groepe om beperkte sosiale, ekonomiese en gebiedshulpbronne meeding; die grootte of politieke mag van mededingende groepe teenstrydigheid of verandering toon; ' $n$ geskiedenis van konflik tussen groepe bestaan, of 
groepe 'n geografiese gebied deel dog uiteenlopende stelsels of persoonlike en sosiale waardes onderskryf (Stanley 1996:115). As ons hierdie insigte op Suid-Afrika toepas, bied dit ons óf geleenthede vir oplossings om mekaar as mense aan te vul, óf struikelblokke waar mededinging en kultuurverskille die 'spiraal van konflik' (Van Aarde 2008a) aanvuur.

Wat die huidige 'rassepolitiek' in Suid-Afrikaanse verband betref, is ' $n$ mens geneig om die hoop op daadwerklike oplossings te laat vaar. Voordat ons onsself egter aan determinisme oorgee, moet ons ons aan Van Aarde (2008a) se insig herinner, naamlik dat die Nuwe Testament wegdoen met die idee dat ons niks aan die huidige aion kan verander nie. Ons hét inderdaad 'n keuse.

Van Aarde (2008a) bepleit ook sterk morele leierskap en verantwoordelike optrede onder die Christelike geloofsgemeenskap in die Suid-Afrikaanse bestel ná apartheid:

In Suid Afrika het Apartheid mense se bestaanmiddele teen hulle sin ontneem en rassisme het mense se waardigheid diep aangetas, sodat die fisiese en emosionele pyn wat berokken is, denke in der waarheid oorstyg. In so ' $n$ konteks is ' $n$ spiraal van konflik natuurlik. Nou is die opbou en handhawing van sosiale kohesie van groot belang. Hierin vervul moraliteit ' $n$ belangrike rol.

(Van Aarde 2008a:1689)

Die moraliteit waarna Van Aarde hier bo verwys, hou verband met 'nuwe denkwyses'; die transformasie van die self. In hierdie verband beteken sterk morele leierskap, leierskap met insig en visie - waar leiers na die 'transformasie van die self' streef, en 'n moraliteit voorstaan wat sosiale samehang bevorder. Uit die insigte van die sosiale-identiteitsteorie leer ons dat een van die beste wyses om intergroepkonflik hok te slaan, die daarstel van 'n omvattende (hoër) identiteit is wat nie subidentiteite ongeldig verklaar nie, maar dit inteendeel bekragtig. Hierdie strategie word selfs doeltreffender wanneer die subidentiteite gemeenskaplike doelwitte koester (vgl. Brown 2000; Dovidio et al. 1998). Dit is presies wat Paulus in die Romeinebrief doen - dít is tog 'n resep vir 'n reënboognasie.

Aan die een kant beteken dit dat ruimtes geskep moet word waar diverse kultuurgemeenskappe die geleentheid kry om diep asem te haal. In dié verband verwys Van Aarde na die gevare van 'n 'totalitêre meesternarratief' of 'heteronormatiewe hegemonie' (Van Aarde 2008a:1690). Die regering sal moet besin oor hul selftoegeëiende reg om, by wyse van spreke, 'in almal se slaai te krap'. Die huidige meesternarratief van 'transformasie', wat op soortgelyke wyse op alle vlakke van die samelewing toegepas word, verg hersiening om die sosiale, politieke, kulturele en ekonomiese belange van 'ons' as subidentiteite te waarborg. Dít beteken dat die regering bereid sal moet wees om terug te staan dat kultuurgemeenskappe in ' $n$ sekere mate hul eie belange bestuur.
Terselfdertyd moet daar ' $n$ inklusiwiteit bestaan waarin etniese groepe mekaar aanvaar en saam 'n samelewing help skep waarin almal se menswaardigheid met onderlinge begrip en liefde erken en bevorder word. ${ }^{3}$ Dit behels onder meer samewerking om gemeenskaplike doelwitte wat 'ons almal' raak, te verwesenlik, en só etniese harmonie te help bewerkstellig. Hierdie gemeenskaplike doelwitte verwys veral na die opheffing van armes; die bestryding van geweld teen vroue en kinders; die bekamping van misdaad, diskriminasie, korrupsie en dwelmmisbruik; werkskepping; die oplossing van die MIV/vigs-epidemie, en professionele opvoeding. Daar moet veral weggedoen word met straks die grootste kwaal van ons huidige samelewing, te wete die alomteenwoordige en alewige slagoffersindroom. Hier val Van Aarde se magnum opus oor die historiese Jesus, waarin die outeur hom met die lot van hawelose kinders bemoei, ' $n$ mens by (Van Aarde 2001). 'n Nuwe denkwyse laat ons besef dat bogenoemde samelewingsake nie 'hulle' probleem is nie, maar 'ons almal s'n'. Dit veronderstel 'n bewussyn waarin die 'buitegroep' deel word van jou 'binnegroep'; waarin 'ons' en 'ons almal' gelyke aandag geniet.

Alle kultuurgroepe, veral die leiers, in Suid-Afrika het die verantwoordelikheid om op die 'spiraal van konflik' (Van Aarde 2008a) te let. Hierin moet die kerkgemeenskappe van Suid-Afrika 'n leidende rol speel. Soos Van Aarde (2008a:1691) wys moet Christene 'eskatologiese hoop' verinnerlik dat 'jy soos God, soos Jesus en soos die Gees die lewe onbeperk vir ander [moet] gun'. Vir eers sluit dít die erkenning en bevordering van kulturele diversiteit in, maar ook dat ons mense mekaar sal komplementeer eerder as om met mekaar te kompeteer.

\section{Bedankings}

Ek skryf hierdie artikel met genoeë en waardering. Ek was bevoorreg genoeg om prof. Andries van Aarde teen die einde van 2003, ná die afhandeling van my magister aan die Universiteit van die Witwatersrand, te ontmoet. In daardie stadium wou ek my doktorale studie op die gebied van 'historiese Jesus'-navorsing doen, en het prof. Bill Domeris my aangeraai om dit onder leiding van prof. Van Aarde aan te pak. My studie onder leiding van prof. Van Aarde het uiteindelik tot ' $n$ tydperk gelei waarin ek my in die sosiaalwetenskaplike benadering tot die eksegese van antieke tekste kon verlustig. Prof. Van Aarde se leiding en veelomvattende kennis het my telkens beïndruk - 'n man wie se nederigheid kop aan kop met sy akademiese uitnemendheid staan. Hierdie navorsingstuk is 'n poging om sy menswees en teologiese benadering tot sensitiewe sosiale vraagstukke te erken, sowel as sy prestasie om sosiaal-wetenskaplike eksegese in Suid-Afrikaanse navorsing te help vestig. Op ' $n$ meer persoonlike noot is dit my manier om te sê: Dankie vir alles, en geseënde 60ste verjaarsdag.

3.Dit is vanselfsprekend dat hierdie standpunt van Paulus op die Christelike .Dit is vanselfsprekend dat hierdie standpunt van Paulus op die Christelike
geloofsgemeenskappe betrekking het, waar Paulus hom meer met ' $n$ inklusiewe evangelie as eksklusiewe etniese belange bemoei het. 


\section{Literatuurverwysings}

Beker, J.C., 1986, 'The faithfulness of God and the priority of Israel in Paul's letter to the Romans', Harvard Theological Review 79, 10-16.

Bell, C., 1997, Ritual: Perspectives and dimensions, Oxford University Press, New York. Bentley, G.C., 1987, 'Ethnicity and practice', Comparative Studies in Society and History 29, 24-55. doi:10.1017/\$001041750001433X

Bourdieu, P., 1977, Outline of a theory of practice, transl. R. Nice, Cambridge Studies in Social Anthropology 16, Cambridge University Press, Cambridge.

Brown, R., 1995, Prejudice: Its social psychology, Blackwell, Oxford. doi:10.1002/1099 0992(200011/12)30:6<745::AID-EJSP24>3.0.CO;2-O

Brown, R., 2000, 'Agenda 2000 - Social identity theory: Past achievements, current problems, and future challenges', European Journal of Social Psychology 30(6),
745-778.

Brown, R., 2001, Group processes: Dynamics within and between groups, 2nd edn. Blackwell, Oxford.

Cohen, S.J.D., 1987, From the Maccabees to the Mishnah, Library of Early Christianity 7, Westminster, Philadelphia.

Cromhout, M., 2007, Jesus and identity: Reconstructing judean ethnicity in Q. Matrix The Bible in Meditterannean Context, Cascade, Eugene, Oregon.

Cromhout, M., 2009, 'Paul's "former conduct in the Judean way of life" (Gal 1:13) ... or not?', HTS Teologiese Studies/Theological Studies 65(1), Art \#127, 12 bl, DOI: 10.4102/hts.v65i1.127

Cromhout, M., 2010, Walking in their sandals: A guide to first-century CE Israelite ethnic identity, Cascade, Eugene, Oregon. (Forthcoming)

Cromhout, M., \& Van Aarde, A.G., 2006, 'A socio-cultural model of Judean ethnicity: A proposal', HTS Teologiese Studies/Theological Studies 62(1), 69-101.

De Vos, G., 1975, 'Ethnic Pluralism: Conflict and Accommodation', in G. de Vos \& L. Romanucci-Ross (eds.), Ethnic identity: Cultural continuities and change, pp 5-41, Mayfield, Palo Alto, Kalifornië.

Dovidio, J.F., Gaertner, S.L, \& Validzic, A., 1998, 'Intergroup Bias: Status, differentiation, and a common ingroup identity', Journal of Personality and Social Psychology 75(1), 109-120. doi:10.1037/0022-3514.75.1.109

Duling, D.C., 2005, 'Ethnicity, ethnocentrism, and the Matthean ethnos', Biblical Theology Bulletin 35, 125-143. doi:10.1177/01461079050350040301

Duling, D.C., 2008a, “"Whatever gain I had ...": Ethnicity and Paul's self-identification in Philippians 3:5-6', HTS Teologiese Studies/Theological Studies 64, 799-818.

Duling, D.C., 2008b, 'Corinthians 11:22: Historical context, rhetoric, and ethnicity', HTS Teologiese Studies/Theological Studies 64, 819-843.

Dunn, J.D.G., 1990, Jesus, Paul and the law: Studies in Mark and Galatians, Westminster John Knox, Louisville, Kentucky.

Dunn, J.D.G., 2008, The new perspective on Paul, rev. version, Eerdmans, Grand Rapids.

Esler, P.F., 1996, 'Group boundaries and intergroup conflict in Galatians: A new reading of Galatians 5:13-6:10', in M.G. Brett (ed.), Ethnicity and the Bible, pp. 215-240, Biblical Interpretation Series 19, E.J. Brill, Leiden.

Esler, P.F., 1998, Galatians, Routledge, Londen/New York.

Esler, P.F., 2003a, Conflict and identity in Romans: The social setting of Paul's letter, Fortress, Minneapolis.
Esler, P.F., 2003b, 'Ancient oleiculture and ethnic differentiation: The meaning of the olive-tree image in Romans 11', Journal for the Study of the New Testament 26, 103-124. doi:10.1177/0142064X0302600106

Esler, P.F., 2003c, 'Social identity, the virtues, and the good life: A new approach to Romans 12:1-15:13', Biblical Theology Bulletin 33, 51-63.

Gruen, E.S., 2002, Heritage and Hellenism: The reinvention of Jewish tradition Hellenistic culture and society 30, University of California Press, Berkeley.

Hall, J.M., 1997, Ethnic identity in Greek antiquity, Cambridge University Press, Cambridge. doi:10.1017/СBO9780511605642

Harland, P.A., 2003, Associations, synagogues, and congregations: Claiming a place in ancient Mediterranean society, Fortress Press, Minneapolis.

Hays, R.B., 2002, The Faith of Jesus Christ: The narrative substructure of Galatians 3:1-4:11, Eerdmans, Grand Rapids, Michigan.

Hooker, M.D., 1990, From Adam to Christ: Essays on Paul, Cambridge University Press, Cambridge.

Johnson, L.T., 1982, 'Rom 3:21-26 and the faith of Jesus', Catholic Biblical Quarterly 44, 77-90.

Malina, B.J., 1993, The New Testament world: Insights from cultural anthropology, 3rd edn., Westminster John Knox, Louisville.

Malina, B.J. \& Neyrey, J.H., 1996, Portraits of Paul: An archaeology of ancient personality, Westminster John Knox Press, Louisville.

Miller, J.C., 2001, 'The Romans debate: 1991-2001', Currents in Research: Biblical Studies 9, 306-349.

Schmidt, F., 2001, How the Temple thinks: Identity and social cohesion in ancient Judaism, transl. J. Edward Crowley, Biblical Seminar 78, Sheffield Academic, Sheffield.

Stanley, C.D., 1996, “"Neither Jew nor Greek”: Ethnic conflict in Graeco-Roman society', Journal for the Study of the New Testament 64, 101-124.

Tajfel, H., 1978, Differentiation between social groups: Studies in the social psychology of intergroup relations, Academic Press, Londen.

Tajfel, H., 1981, Human groups in social categories: Studies in social psychology, Cambridge University Press, Cambridge.

Tajfel, H. \& Turner, J.C., 1979, 'An integrative theory of intergroup conflict', in W.G. Austin \& S. Worchel (eds.), The social psychology of intergroup relations, pp. 33-47, Brooks/Cole Publishing, Monterey, Kalifornië.

Taylor, W.F., 2002, 'Unity/unity of humanity', in D.N. Freedman (ed.), The Anchor Bible Dictionary, vol. 6, pp. 746-753, Doubleday, New York.

Taylor, W.F., 2005, 'Reciprocity, siblings, and Paul: Why act ethically?', Lutheran Theological Journal 39, 181-195.

Van Aarde, A.G., 2001, Fatherless in Galilee: Jesus as child of God, Trinity Press International, Harrisburg, Pennsilvanië.

Van Aarde, A.G., 2008a, 'Paulus se versie van "draai die ander wang" - gedagtes oor geweld en toleransie', HTS Teologiese Studies/Theological Studies 64(4), 1667-1697.

Van Aarde, A.G., 2008b, "The RDP of the Soul", geweld, toleransie en Paulus se appè om moed te hou', Verbum et Ecclesia 29(3), 708-727.

Van Eck, E., 2009, 'Inklusiwiteit as evangelie', HTS Teologiese Studies/Theological Studies 65(1), Art \#304, 10 bl, DOI: 10.4102/hts.v65i1.304. 